Original Research Paper

\title{
Mitigasi Bencana Abrasi Pantai Melalui Penanaman Mangrove di Desa Seriwe, Jerowaru Lombok Timur
}

\author{
Elya Kartika Rinjani ${ }^{1}$, Nurhidayah ${ }^{1}$, Septi Panbriani ${ }^{1}$, Ummi Auliya' Amalina $^{1}$, I Putu Artayasa ${ }^{1 *}$ \\ ${ }^{1}$ FKIP Universitas Mataram, Mataram, Indonesia
}

https://doi.org/10.29303/jpmpi.v3i2.1419

Sitasi: Rinjani, E. K., Nurhidayah., Panbriani, S., Amalina, U. A \& Artayasa, I. P. (2022). Mitigasi Bencana Abrasi

Pantai Melalui Penanaman Mangrove di Desa Seriwe, Jerowaru Lombok Timur. Jurnal Pengabdian Magister

Pendidikan IPA, 5(1)

Article history

Received: 11 Januari 2022

Revised: 11 Februari 2022

Accepted: 27 Februari 2022

*Corresponding Author: I Putu Artayasa,Universitas Mataram, Mataram, Indonesia;

Email:

artayasa75@unram.ac.id

\begin{abstract}
Mangrove forest ecosystem is an important habitat for marine biota and as a coast guard from abrasion. One area that has mangrove forests and is quite vulnerable to abrasion is Seriwe Village, Jerowaru District, East Lombok, NTB. This service activity aims to increase public awareness about the importance of mangrove planting as a disaster mitigation effort in preventing abrasion, especially in Seriwe Village. The activity was carried out by providing counseling to the Seriwe community about the importance of mangrove plants for the life of marine biota, preventing abrasion, and assisting the community in planting mangroves on the coast around the village. This activity involved the University of Mataram Integrated Community Service Program students and villagers. The results of the service showed that this activity ran smoothly and was followed by quite high enthusiasm by all participants. It is hoped that with this activity, the Seriwe Village community can understand and take advantage of mangroves to prevent Seriwe Village from abrasion.
\end{abstract}

Keywords: Seriwe; Disaster Mitigation; Abrasion; Mangrove

\section{Pendahuluan}

D esa Seriwe adalah salah satu desa di Kecamatan Jerowaru yang berada di Kabupaten Lombok Timur. Desa Seriwe merupakan desa terpencil dengan luas $150 \mathrm{~km} 2$ yang terdiri dari delapan dusun (Gambar 1). Desa Seriwe merupakan hasil pemekaran dari Desa Pemokong Kecamatan Jerowaru tahun 2009. Secara umum kondisi iklim di wilayah Desa Seriwe tidak berbeda nyata dengan daerah lain di Kabupaten Lombok Timur bagian selatan, yaitu musim kemarau yang berlangsung pada bulan April sampai dengan September. Musim hujan. dari Oktober hingga Maret. (Anonim.2022).

Desa Seriwe merupakan daerah padat penduduk. Dusun Seriwe merupakan dusun terpadat dari delapan dusun di Desa Seriwe memiliki jumlah KK 476, dengan jumlah Jiwa lakilaki 747 jiwa sedangkan yang perempuan berjumlah 643 jiwa. Dusun Temodo dengan jumlah KK 279 memiliki penduduk laki-laki 408 jiwa, sedangkan perempuan 409 jiwa. Dusun Kaliantan dengan Jumlah KK 267 terdiri 432 laki-laki dan 376 perempuan (Data Desa Seriwe). Sebagian besar penduduk Desa Seriwe mendiami daerah pesisir pantai. sehingga mata pencaharian utama masyarakat Desa Seriwe bersumber dari laut. Seiring berjalannya waktu akibat dari perubahan alam dan kegiatan masyarakat di daerah pesisir pantai Seriwe menyebabkan Desa Seriwe sering mengalami abrasi.

Abrasi atau erosi adalah kerusakan garis pantai akibat dari terlepasnya material pantai, seperti pasir atau lempung yang terus menerus dihantam oleh gelombang laut atau dikarenakan oleh terjadinya perubahan 
keseimbangan angkutan sedimen di perairan pantai atau hilangnya daratan di wilayah pesisir. (Munandar \& Kusumawati, 2017). Fenomena abrasi disebabkan oleh faktor alami dan manusia. Proses-proses alami dapat berupa proses hidro-oseanoografi, dari laut misalnya akibat hempasan gelombang, perubahan pola arus, angin dan fenomena pasang surut yang kesemuanya dapat menyebabkan abrasi pantai. Disamping itu, kenaikan permukaan air laut akibat pemanasan global semakin memperparah kondisi perairan pantai. Pemanasan global merupakan fenomena peningkatan temperatur global dari tahun ke tahun karena terjadinya efek rumah kaca (greenhouse effect) yang disebabkan oleh meningkatnya emisi gas-gas seperti karbondioksida (C02), metana (CH4), dinitro oksida (N20) dan CFC sehingga panas dari energi matahari terperangkap dalam atmosfer bumi (Munandar \& Kusumawati, 2017).

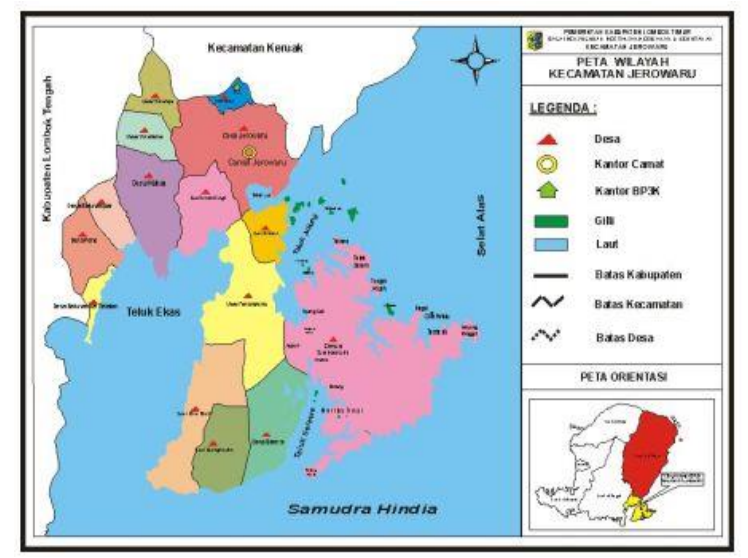

Gambar 1 Peta Desa Seriwe

Sumber : Data Desa Seriwe

Daratan yang terlalu sering terkena air laut menyebabkan terjadinya abrasi, dimana tanah menjadi semakin terkikis dan menyempit. Hal ini menyebabkan berkurangnya luas daratan dan dapat dengan mudah membawa air laut ke permukaan (Bekti et al., 2017). Wilayah pesisir merupakan ekosistem peralihan yang dipengaruhi oleh daratan dan lautan, Salah satu dari ekosistem di wilayah pesisir ini adalah mangrove. Ekosistem mangrove dapat mencegah terjadinya abrasi (Soraya et al., 2012). Abrasi sangat berbahaya bagi kehidupan masyarakat pesisir pantai. dimana jika terjadi secara terus menerus dapat menggerus daratan yang menyebabkan pemukiman penduduk pesisir juga akan tergerus. Oleh karena itu perlu dilakukan penanganan bencana abrasi secara berkelanjutan melalui mitigasi bencana. Ada dua metode untuk menjaga lingkungan pesisir yaitu melalui perlakuan struktural dan non-struktural. Perlakuan struktural/fisik yaitu menciptakan struktur pelindung tertentu, baik alami maupun buatan, untuk mencegah degradasi lingkungan yang ada di wilayah pesisir. Sedangkan secara buatan dapat dibuat tanggul (Suci,.2020).

$$
\text { Penanganan bencana (disaster }
$$
management) merupakan proses yang dinamis, terpadu dan berkelanjutan untuk meningkatkan kualitas langkah-langkah yang berhubungan dengan serangkaian kegiatan yang meliputi pencegahan (preventive), mitigasi, kesiapsiagaan (preparedness), tanggap darurat, evakuasi, rehabilitasi dan pembangunan kembali (reconstruction). Sedangkan mitigasi adalah merupakan tindakan-tindakan untuk mengurangi atau meminimalkan potensi dampak negatif dari suatu bencana. Kegiatan mitigasi merupakan salah satu bagian dari kegiatan penanganan bencana yang difokuskan untuk mengurangi potensi dampak yang mungkin ditimbulkan oleh bencana yang diprediksikan akan terjadi di masa datang. (Jokowinarno.2011).

Mangrove merupakan kawasan bertemunya daratan dan lautan. Mangrove didefinisikan sebagai komunitas yang hidup di daerah basah dan berlumpur dan dipengaruhi oleh pasang surut air laut (Muhammad et al., 2013). Hutan mangrove merupakan kawasan yang memiliki potensi besar. Hutan mangrove memiliki potensi untuk dimanfaatkan secara tidak langsung dan ekonomis (langsung) sebagai salah satu sumber daya wilayah pesisir (Syah, 2020). Mangrove melakukan banyak fungsi termasuk perlindungan gelombang, abrasi, perlindungan intrusi, habitat bagi berbagai spesies dan tanaman tersedia untuk digunakan manusia (Mudmainah, 2015). Berdasarkan uraian di atas maka salah satu langkah mitigasi yang dilakukan untuk mencegah abrasi pantai di Desa Seriwe yaitu dengan melakukan penyuluhan pentingnya komunitas mangrove bagi biota laut serta penanaman mangrove di daerah pesisir pantai Desa Seriwe.

\section{Metode}

Kegiatan ini dilakukan pada tanggal 25 Desember 2021 di muara Desa Seriwe, Kecamatan Jerowaru, Kabupaten Lombok Timur. Kegiatan ini 
dilakukan oleh Mahasiswa KKN TERPADU FKIP Universitas Mataram dengan warga Desa Seriwe. Bahan yang digunakan dalam kegiatan ini adalah bibit mangrove, tali rafia, dan bambu sebagai pasak. Bibit mangrove diperoleh dari BPDASHL (Balai Pengelolaan Daerah Aliran Sungai \& Hutan Lindung) Kantor cabang Pringgabaya, Lombok Timur.

Kegiatan ini bertujuan untuk memberikan penyuluhan dan pendampingan kepada masyarakat bagaimana penanaman mangrove dengan baik dan benar untuk mencegah bencana abrasi. Bibit mangrove yang ditanam berjumlah 300 bibit yang sesuai untuk melengkapi lahan kosong yang perlu ditanami mangrove seluas kurang lebih $300 \mathrm{~m}^{2}$ (Gambar 2). Penanaman mangrove dilakukan secara bergotong royong melibatkan mahasiswa KKN Terpadu Universitas Mataram dan masyarakat Setempat.

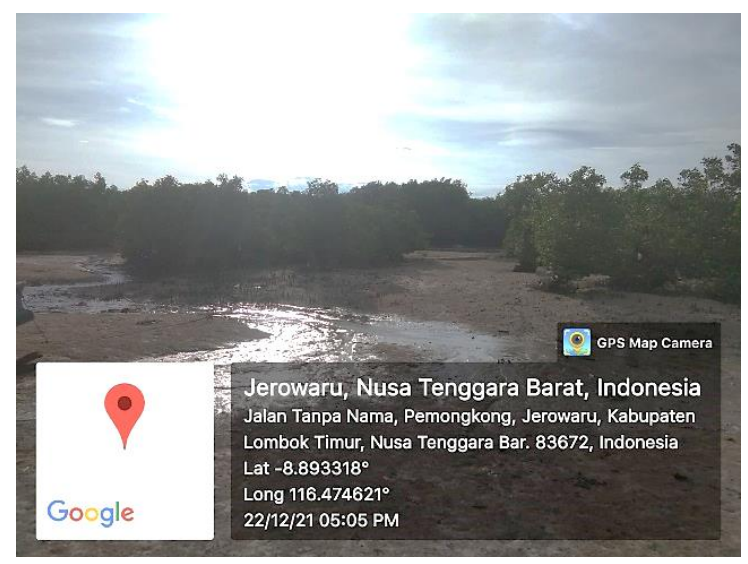

Gambar 2. Lokasi Penanaman Mangrove

\section{Hasil dan Pembahasan}

Salah satu upaya mitigasi bencana untuk mengatasi masalah abrasi Desa Seriwe adalah penanaman mangrove di muara dan sepanjang pesisir pantai. Kegiatan ini melibatkan Mahasiswa KKN Terpadu Universitas Mataram dan warga Desa. Penanaman mangrove dilakukan di lahan seluas kurang lebih $300 \mathrm{~m}^{2}$ dengan bibit sebanyak 300 bibit (Gambar 3). Hasil pengabdian menunjukkan kegiatan ini berjalan dengan lancar dan diikuti dengan antusias yang cukup tinggi oleh seluruh peserta. Adanya kegiatan ini menyebabkan masyarakat Desa Seriwe dapat memahami dan mengambil manfaat besar yang dimiliki oleh mangrove serta dapat berdampak mencegah Desa Seriwe dari abrasi.

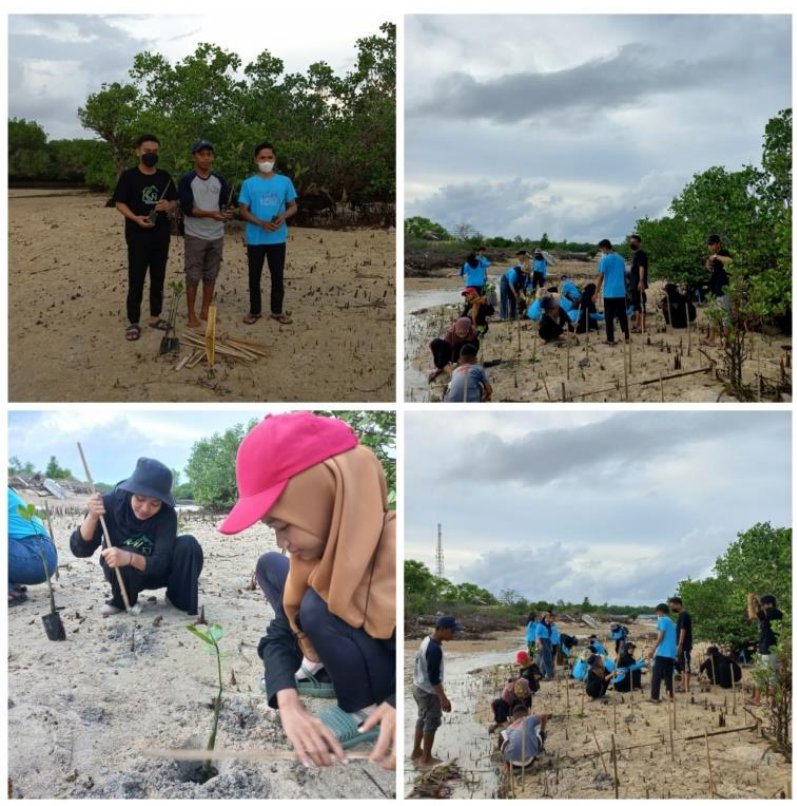

Gambar 3. Penanaman mangrove di Desa Seriwe

Penanaman mangrove merupakan langkah utama pencegahan abrasi yang paling umum dapat dilakukan. Mitigasi bencana abrasi dengan penanaman mangrove diharapkan dapat mengurangi potensi abrasi di Desa Seriwe di masa mendatang. Secara ekologi tanaman ini efektif melindungi wilayah pesisir. Dari segi ekonomi dan lingkungan, perairan mangrove berfungsi sebagai tempat berkembang biaknya berbagai hewan air yang bernilai ekonomis tinggi, seperti ikan, udang, kepiting, dan kerang. Secara fisik bertindak sebagai penghalang terhadap abrasi pantai, intrusi air laut, badai dan angin sarat garam, juga mengurangi karbon dioksida (CO2) di udara dan menjebak kontaminan di perairan pantai (Munandar \& Kusumawati, 2017).

Penanaman mangrove di muara Desa Seriwe dilakukan dengan menggunakan sistem zonasi. Diharapkan keberadaan mangrove dapat mengembalikan kerusakan lingkungan dan mendukung mata pencaharian masyarakat di sekitar wilayah pesisir yang umumnya sebagai nelayan, juga dapat memperindah pantai sehingga meningkatkan daya tarik wisatawan untuk berkunjung di Desa Seriwe. Hal ini sesuai dengan pendapat Sumar (2021) tentang beberapa manfaat dari hutan mangrove, yaitu: 
1. Mencegah Intrusi Air Laut

Intrusi laut merupakan peristiwa perembesan air laut ke tanah daratan. Intrusi laut dapat menyebabkan air tanah menjadi payau sehingga tidak baik untuk dikonsumsi. Hutan Mangrove memiliki fungsi mengendapkan lumpur di akar-akar pohon bakau sehingga dapat mencegah terjadinya intrusi air laut ke daratan.

2. Mencegah Erosi dan Abrasi Pantai

Erosi merupakan pengikisan permukaan tanah oleh aliran air sedangkan abrasi merupakan pengikisan permukaan tanah akibat hempasan ombak laut. Hutan Mangrove memiliki akar yang efisien dalam melindungi tanah di wilayah pesisir, sehingga dapat menjadi pelindung pengikisan tanah akibat air.

3. Sebagai pencegah dan penyaring alami

Hutan mangrove biasanya yang dipenuhi akar pohon bakau dan berlumpur. Akar tersebut dapat mempercepat penguraian limbah organik yang terbawa ke wilayah pantai. Selain pengurai limbah organik, hutan mangrove juga dapat membantu mempercepat proses penguraian bahan kimia yang mencemari laut seperti minyak dan deterjen, dan merupakan penghalang alami terhadap angin laut yang kencang pada musim tertentu.

4. Sebagai tempat hidup dan sumber makanan bagi beberapa jenis satwa

Hutan Mangrove juga merupakan tempat tinggal yang cocok bagi banyak hewan seperti biawak, kura-kura, monyet, burung, ular, dan lain sebagainya.

5. Berperan dalam pembentukan pulau dan menstabilkan daerah pesisir.

Hutan mangrove seringkali dikatakan pembentuk daratan karena endapan dan tanah yang ditahannya menumbuhkan perkembangan garis pantai dari waktu ke waktu. Pertumbuhan mangrove memperluas batas pantai dan memberikan kesempatan bagi tumbuhan terestrial hidup dan berkembang di wilayah daratan.

Mitigasi bencana abrasi melalui penanaman mangrove sangat bermanfaat, baik bagi manusia maupun bagi alam di masa depan. Oleh karena itu penting menumbuhkan kesadaran masyarakat Desa Seriwe untuk menjaga mangrove dengan tidak mengeksploitasi mangrove secara berlebihan, karena mangrove memiliki banyak sekali manfaat salah satunya menjaga pantai dari abrasi dengan cara melindungi daratan dari hempasan ombak sehingga ombak tidak menerjang daratan secara langsung.

\section{Kesimpulan}

Kegiatan yang dilakukan dengan memberikan penyuluhan kepada masyarakat Desa Seriwe tentang pentingnya tanaman mangrove bagi kehidupan biota laut, pencegahan abrasi, serta mendampingi masyarakat dalam penanaman mangrove di pantai sekitar desa tersebut mendapat respons yang sangat baik dari masyarakat Desa Seriwe. Masyarakat sangat berharap dengan adanya kegiatan ini bencana abrasi dapat dicegah dan dapat mengurangi kerusakan daerah pesisir tempat tinggal Masyarakat.

\section{Saran}

Kegiatan pengabdian penanaman mangrove yang dilakukan oleh mahasiswa KKN TERPADU Unram di Desa Seriwe, kecamatan Jerowaru, kabupaten Lombok Timur merupakan hal yang sangat penting dilakukan karena dapat meningkatkan pemahaman masyarakat akan pentingnya mangrove dan juga dapat digunakan sebagai strategi mitigasi bencana abrasi pantai di Desa Seriwe, sehingga kegiatan yang telah dilakukan tersebut perlu diteruskan agar dapat mempertahankan keberadaan hutan mangrove di desa tersebut

\section{Ucapan Terima}

Ucapan terima kasih disampaikan kepada semua yang terlibat dalam kegiatan penanaman mangrove ini khususnya masyarakat desa Seriwe yang banyak membantu dan mendukung kegiatan ini sehingga dapat terlaksana dengan baik. Ucapan terimakasih juga disampaikan kepada kepala Balai Pengelolaan Daerah Aliran Sungai dan Hutan Lindung, Kantor cabang Pringgabaya, Lombok Timur yang telah mendukung dengan pemberian bibit mangrove. 


\section{Daftar Pustaka}

Anonim. (2022). Desa Seriwe. Diperoleh dari https://www.kompasiana.com/kknterpaduse riwe255487/61d0f6621667172efb2fb6d2/s ejarah-peradapan-desa-seriwe-kecamatanjerowaru-lombok-timur.

Bekti, U., Budiastuti, S., \& Muryani, C. (2017). Strategi Pengelolaan Hutan Mangrove Di Desa Tanggul Tlare Kecamatan Kedung Kabupaten Jepara. Jurnal Ilmu Lingkungan. 15 (2). .

Jokowinarno, J. (2011). Mitigasi Bencana Tsunami di Wilayah Pesisir Lampung. Jurnal Rekayasa.. 15(1). 13-20. Diperoleh dari https://media.neliti.com/media/publications /139673-ID-mitigasi-bencana-tsunami-diwilayah-pesi.pdf

Mudmainah, V. (2015). Kerentanan Ekosistem Mangrove terhadap Ancaman Gelombang Ektrim/Abrasi Di Kawasan Konservasi Pulau Dua Banten. Bioedukasi. 8(2)..

Muhammad, N., Nasruddin, Wasiq, J., \& Sumariyah. (2013). Penerapan Teknologi Plasma Untuk Mempercepat Persemaian Mangrove Sebagai Upaya Rehabilitasi Green Belt Untuk Mengatasi Abrasi. Riptek. 7(1), 15-26. Diperoleh dari https://www.researchgate.net/publication/3 34130480

Munandar \& Kusumawati, I. (2017). Studi Analisis Faktor Penyebab Dan Penanganan Abrasi Pantai di Wilayah Pesisir Aceh Barat. Jurnal Perikanan Tropis. 4(1), 47-56. DOI: https://doi.org/10.35308/jpt.v4i1.55

Soraya, D., Suhara, O., \& Taofiqurohman, A. (2012). Perubahan Garis Pantai Akibat Kerusakan Hutan Mangrove di Kecamatan Blanakan dan Kecamatan Legonkulon, Kabupaten Subang. Jurnal Perikanan dan Kelautan. 3(.4), 355-364. Diperoleh dari https://media.neliti.com/media/publications /125648-ID-perubahan-garis-pantai-akibatkerusakan.pdf

Suci, R. (2020). Pencegahan Abrasi Pantai Timur Surabaya Melalui Desain Ekowisata Hutan Mangrove Wonorejo Surabaya. Prosiding Seminar Teknologi Kebumian dan Kelautan. 2(1), 535-541. DOI: https://doi.org/10.31284/p.semitan.20 $\underline{20.1007}$
Sumar. (2021). Penanaman Mangrove Sebagai Upaya Pencegahan Abrasi Di Pesisir Pantai Sabang Ruk Desa Pembaharuan. IKRAITHABDIMAS. 4(1), 126-130. Diperoleh dari https://journals.upiyai.ac.id/index.php/IKRAITHABDIMAS/article/view/894/685

Syah, F. A. (2020). Penanaman Mangrove Sebagai Upaya Pencegahan Abrasi di Desa Socah Kabupaten Bangkalan. Jurnal Pangabdhi. 6(1), 13-16. DOI: https://doi.org/10.21107/pangabdhi.v $\underline{6 i 1.6909}$ 